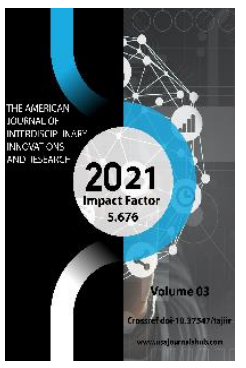

Journal Website: http://usajournalshub.c om/index,php/tajiir

Copyright: Original content from this work may be used under the terms of the creative commons attributes 4.0 licence.

\section{The Implementation Of Makom Music Genre Into The Creative Works Of Uzbek Music Composers (In 1930-1990)}

\author{
Samandar Kuzievich Khudayberganov \\ Professor Of The Department Of Music Education, Urgench State University, Uzbekistan \\ Sarvarbek Uktamboy O'G 'Li Yo 'Ldoshev \\ The 3 rd Course Student Of The Department Of Music Education, Urgench State University, \\ Uzbekistan
}

\title{
ABSTRACT
}

This article reveals the essence of the study of the practical basis of Uzbek makoms, the use of maqom, national melodies by the Uzbek music composers. The delineation of Uzbek makoms in the music compositions, the performers of a wide range of national makom music, and the aspects that should be considered, are explained. The creative works by a number of Uzbek composers are also considered.

\section{KEYWORDS}

Uzbek music, music art of maqom, national music, Shashmaqom, compositional creativity, musicology, Uzbek opera, Uzbek musical dramas, theory of music, music forms.

\section{INTRODUCTION}

The roots of Uzbek music go back to ancient times. A number of its genres and forms have evolved over the centuries. Today, folk music and national classical music have become two huge layers of Uzbek musical culture. Creation of new songs and music composition can be 
defined as the important aspects of Uzbek music in line with the times, as an important feature in the expansion and enrichment of the Uzbek musical heritage.

Uzbek national classical music is distinguished by its wide range and rich heritage. In particular, the issue of examples of maqom series conveys one of the leading positions in modern music studies. In our opinion, Khorezm maqom series, are of great interest among musicians in this regard along with the Bukhara Shashmaqomi, Fergana-Tashkent maqom roads. In particular, it is important to study the unique and diverse new forms of Khorezm maqoms, their structure, performance traditions, well-known representatives, and notation of music heritage.

National makoms, like other phenomena of society, have lived in dependence on the social, artistic and aesthetic requirements and needs of the time. It has also undergone major changes in its process of development. Shashmaqom, being a classic example of Uzbek-Tajik music art, emerged as an independent music genre in the first half of the 18th century. The maqoms are a series of musical complexes created in a certain order, a carefully polished genre of music sculpture of the past . In a broad sense, maqoms are an encyclopedia of folk music. As it, especially Shashmaqom bases on a number of aspects of Uzbek folk music, the melodies, rhythmic features, methods of playing the doira, the rules of connection of poetry and folk songs. Therefore, at present, serious attention is paid to the study of the issues of makom, the identification and mastering of methods of the performance of makom. Shashmaqom plays an important role in the musical heritage of the
Uzbek people. The instrumental and singing tracks of this series of maqoms contain a number of aspects related to the rich tones of national music, rhythmic features, the methods of playing the doira, as well as the rules of adapting poetic texts to melodies. No matter which of the works of folk music you take, it is not difficult to know whether they are similar to this or that makom, or its branch melody, melody structure, and the method of playing the doira. The subsequent observations suggest that Shashmaqom forms the basis of the folk musical heritage.

If we pay attention to the composition of Shashmaqom, it includes about 250 musical and singing tracks. If we take into account the hundreds of samples of folk melodies and songs created on their basis, the way of playing the trumpet, we can once again see how wide the position of maqoms in folk music is. The fact is that Shashmaqom was always in touch with folk art and that it was constantly enriched, developed and reflected in the historical sources of music.After all, today this direction is experiencing its period of perfection. The achievements in performance and delivering makom from one generation to the next of our time and consideration of it as the musical heritage of the Uzbek people as well as the works created on various topics serve as a proof of our opinion.

Over the past half century, Uzbek art of music composition has developed in all directions. In particular, it could enter the world of music and has taken its place. Considering the creative works of most of Uzbek composers, it can be observed that the features of nationalism and tradition are more important in them. There are a lot of issues of the style and factors in the 
art of music creation. the creation of modern works based on the national musical heritage, the interpretation of new means play a special role in the work of modern composers of music among them.

Modern Uzbek music art is developing dynamically in Uzbekistan. The composers are creating unique works on the basis of existing maqom series. It can be confirmed with the fact that there were $M$. Ashrafiy, M. Burhanov, I. Akbarov, S. Boboev, M. Liviev, H. Rakhimov, D. Zokirov, D. Soatkulov, O. Khalimov, I. Hamroev, Sh. .Ramazanov, S.Yudakov, I.Akbarov, F.Nazarov, A.Muhammedov, M.Yusupov, S.Jalil, R.Hamroev, M.Tojiev, M.Mahmudov, A.Otajonov, M.Bafoev, N.Norxo'jaev The works of A.Mansurov, F.Olimov, A.Ergashev and E.Solikhov among the Uzbek composers whose creative maturity coincided with the post-war years.

On accordance with the tenth anniversary of the Republic of Uzbekistan, the expert on the Uzbek folk music heritage, composer V.A. Uspensky was tasked to stage musical drama Farhod and Shirin with new improvisation. There should have been a symphony orchestra instead of folk instruments. In carrying out this serious task, the outstanding music composer has achieved great success as a result of his excellent artistic taste and careful work.

Also, the great thinker of Uzbek literature Alisher Navoi's epics in a new spirit play an important role in the history of musical theater. the performance of a play Farhod and Shirin became the "first pioneer" in this field, The play was based on Navoi's epic with the same title and the music of the play consists of pieces from maqoms and other samples of national classical music which performed by the singers accompanied by an ensemble of folk instruments.

When writing the music of the drama Farhod and Shirin, V. Uspensky gave musical patterns mixed with conversations (dialogues) by taking into account the main features of the genre of musical drama. The feelings of love that Farhod and Shirin express to each other were expressed through maqom and classical songs. For example, Farhod arias Dugoh-Husseini, Miskin, Bayot, Dugoh II, Chorgoh IV, Suvora, Chorgoh III, and Shirin arias Naylaram, Dugoh $\mathrm{V}$, Rajabi and Mogulcha are based on maqom and songs. The duet of the two lovers is harmonized in Chorgoh II and Farhod's duet with his friend Shopur was composed in Fergana style of maqom. Before writing the score for Farhod and Shirin, he tried to present to the audience such harmonious songs as Bayot, Husseini, Naylaram, Dugohi Husseini, Gulyori Shakhnoz. These songs were performed by Uzbek singers in a special concert in the symphony orchestra concert and were welcomed by the audience warmly.

Gulsara the melodies Qari-Navo and Segoh are the leading themes in Glier's musical drama. Iraq, Segoh, Shakhnoz-Gulyor, Ushshak, Chorzarb, Chorgoh, Uzbek, Tajik, Arabic folk songs such as Bayot, Chapandozi gulyor, Qalandar II and many other national music created by the composers T.Sadikov and R.Glier to the lyric epic Layli and Majnun by the playwright Sh.Khurshid in collaboration, left a deep mark on the hearts of the audience as the masterpiece.

The composer Tokhtasin Jalilov used the makom of Choli Iraq (Desert of Iraq) in the performance of the flute in Halima. This melody is heard as a 'light theme'in the 
development of the play. During the transition, the aria Uyghot(Awakening) by Nemat based on the makom of Iraq in flute joins.

The aria Muhabbat otida kuydim (Burned in your fire of love) is polished with the intonations of the makom of Dugoh in the musical stage work Nurkhan dedicated to historical figures by the composers T.Jalilov and G.Sobitov.

Musical drama Muqimiy by T. Jalilov and G. Mushel differs in composition I and IV versions of the play. These scenes are enriched with different music genres, among them are Chorgoh, Bayot, Iraq.

The maqom of Sarakhbori Navo and Navo perfectly reveals Burkhanov the theme Navoi in the vocal-symphonic music in The Ode to Alisher Navoi by M.Burhonov. The lyrical suite Dilbarim by the composer B. Umidjanov was based on the classical makom genre. It was designed for two soloists and a choir acapella using such maqoms as Chorgoh, Segoh, Sarakhbori Navo which was performed at the International Symposium "Makom and Mugham in the Performance of Modern Composers" in 1978 in Samarkand. The composer A. Kozlovsky has appealed to Sarakhbori Navo (as a song from makom Navo) in the dramatic plan of the poem Doston. The poem Segoh by the composer S.Boboev combines the melody Segoh and Ufori Segoh. The makom was used as the theme of the creation of modern music performance as well, for instance Segoh in poem Shoir sevgisi(Poet's love) by M. Tojiev, the makom of Buzruk and Sarakhbori Buzruk in the polyphonic work by $\mathrm{T}$. Kurbanov and Segoh in the Fifth Symphony dedicated to Hamza. D.Soatkulov used Tanavor in the first part of his Fergana Quartet and
Mogulchai Mungojat in the final part of it. V. Uspensky used some melodies from the series Dugohi Husseini for the tenor and orchestra in the first and second parts of the composition.

In conclusion, it can be said that our national classical music, that is, maqom and classical melodies, was the basis for the creation of a new interpretation of the composer's work, on the other hand, it can be said that the new "life" is expressed in a unique way. A fresh look at the classic traditional genres can serve as a major factor for all-round perfect level compositions. the interpretation of our classical songs in foreign musical instruments and forms can be said to be the impetus for the development and progress of musical culture for the new generation. Consequently, the works of the above-mentioned composers are a clear proof of the point.

\section{REFERENCES}

1. Fitrat A. Uzbek classical music and its history. T., 1993.

2. Rajabov I. Fundamentals of Makom. T., 1992.

3. Jabborov A. Music Genres of Drama and Comedy used in the Masterpieces of Uzbek composers. T., 2000.

4. Solomonova T. History of Uzbek Music. T., 1981.

5. Yearbook: Tashkent and Music Culture Development in Uzbekistan. T., 2009

6. M.A. Rosenberg. The Genre of Solo VocalSymphonic Poem in Uzbekistan;The scientific problems of music in Uzbekistan. -Tashkent, 1973. -P.74

7. Veksler S. Glier and Uzbek music. T., 1981. 